\title{
THE HYPOLIPIDEMIC AND ANTI-INFLAMMATORY ACTIVITY OF BORONATED AROMATIC AMINO ACIDS IN CF 1 MALE MICE
}

\author{
Merrill C. Miller, III', A. Sood ${ }^{2}$, Bernard F. Spielvogel' ${ }^{2}$, and Iris H. Hall ${ }^{1 *}$ \\ ${ }^{1}$ Division of Medicinal Chemistry and Natural Products, University of North Carolina, Chapel Hill, \\ North Carolina 27559-7360, USA \\ ${ }^{2}$ Boron Biologicals, Inc., Raleigh, North Carolina, 27606, USA
}

\begin{abstract}
The boronated aromatic amino acids were shown to be potent hypolipidemic agents in mice lowering both serum cholesterol and triglycerides after 16 days. Selective compounds were as effective as the clinical standards. Furthermore, the compounds were effective anti-inflammatory agents reducing local and central pain as well as suppressing LPS induced endotoxic shock in mice. These agents inhibited lysosomal and proteolytic enzymes of the liver and macrophages as a part of their mechanism of action.
\end{abstract}

\section{INTRODUCTION}

L-Phenylalanine, tyrosine, proline, histidine and tryptophan boronated derivatives as well as their metal complexes have recently been shown to be potent antineoplastic or cytotoxic agents [1-6]. Previously with the boron analogues of $\alpha$-amino acids, i.e amine-carboxyboranes, heterocyclic amine boranes and 2'deoxynucleoside boranes other biological activities, e.g. hypolipidemic [7-13], antiarthritic, antiinflammatory, antiosteoporoeous[14-19] have been demonstrated in rodents. The present investigation involved the examination of boronated aromatic amino acids as potent hypolipidemic or anti-inflammatory agents in mice at $8 \mathrm{mg} / \mathrm{kg}$, I.P.

\section{MATERIAL AND METHODS \\ Source of Compounds}

All of the boronated aromatic amino acids or their metal complexes were synthesized and published previously: 2-[(N-methylmethanamine)methyl-carbonyl]amino-3-phenyl-methyl propanoate 3 [6], ], (N,Ndimethylmethanamine)dihydro[[[1-(phenylmethyl)-2-methoxy-2-oxoethyl]amino]carbonyl]boron 4 [3], (Nmethylmethanamide)dihydro[[[1-(phenylmethyl)-2-methoxy-2-oxoethyl]amino]carbonyl]boron $5 \mathbf{5}$ [3]; (methanamine)dihydro[[[1-phenylmethyl)-2-methylamino-2-oxoethyl]amino]carbonyl]boron 6 [3], sodium -2(N,N-dimethylmethanamine)dihydroboron-carbonyl]amino-3-phenyl-propanoate $7[5]$, tetrakis- $\{2-[\mathrm{N}, \mathrm{N}-$ dimethylmethanamine)dihydroboron-carbonyl]amino-3-phenyl-propyl carboxylate $\}$-bis- $\{2$-[N,N-dimethylmethanamine)dihydroboron-carbonyl]amino-3-phenyl-propanoate\} dicopper(II) 8 [5], (ammonia)dihydro[[[1(phenylmethyl)-2-methoxy-2-oxoethyl]amino]carbonyl] boron 9 [3], (N,N-dimethyl-methanamine)dihydro[[[1-(4-hydroxyphenyl)-methyl)-2-methoxy-2-oxoethyl]amino]carbonyl]boron $\quad 10 \quad[3], \quad(\mathrm{N}-$ methylmethanamide)dihydro[[1-[(4-hydroxyphenyl)-methyl]-2-methoxy-2-oxoethyl]amino]carbonyl]boron 11 [3], (methanamine)dihydro[[1-[(4-hydroxyphenyl)-methylamino-2-oxoethyl]amino]carbonyl]boron $12 \quad[3]$, (ammonia)dihydro[[[1-(4-hydroxyphenyl)-methyl)-2-amino-2-oxoethyl]amino]carbonyl]boron 13 [3], (cyano)dihydro[[1-(phenylmethyl)-2-amino-2-oxoethyl]amino]boron $\mathbf{1 4} \quad[3], \quad$ N-acetyl-4boronphenylalanylphenylalanine methyl ester 15 [2], N-acetyl-4-boronphenylalanyltyrosine methyl ester 16 [2], N-[(trimethylamineboryl)-carbonyl]-L-histidinemethyl ester 17 [4], N-[(trimethylamineboryl)-carbonyl]Ltryphophan methyl ester 18 [4]. N-[(trimethylamineboryl)-carbonyl] -L-proline methyl ester 19 [2]. Lphenylalanine 1 [Alrich Chemical Co.], L-phenylalanine methyl ester hydrochloride 2 [Aldrich Chemical, Co.] were purchased commercially.

All substrates, co-factors and standard drugs were purchased from Sigma Chemical Co.

\section{Pharmacological Methods}

Hypolipidemic Assay.

$\mathrm{CF}_{1}$ male mice $(\sim 28 \mathrm{~g})$ were administered drugs prepared in $1 \%$ carboxymethylcellulose [CMC] by homogenization at $8 \mathrm{mg} / \mathrm{kg} / \mathrm{day}$, I.P. for 16 days. On days 9 and 16 the mice were bled from the tail vein collected in capillary tubes which were centrifuged at $3000 \mathrm{xg}$ for $3 \mathrm{~min}$. Total cholesterol was determined on the serum using the Libermann-Burchard method [20] determined at $620 \mathrm{~nm}$. Serum triglycerides were determined on day 16 using commerical kits from Sigma Chemical, Co. read at $580 \mathrm{~nm}$. Clofibrate was determined at $150 \mathrm{mg} / \mathrm{kg} /$ day I.P. and lovastatin was determined at $8 \mathrm{mg} / \mathrm{kg} /$ day I.P., which are the drugs' standard therapeutic doses. 
<smiles>NC(Cc1ccccc1)C(=O)O</smiles>

$$
\text { L-Phenylalanine }
$$

I-(phenylmethyl)-2-hydroxy-2-ethyl amine<smiles>COC(=O)C([NH3+])Cc1ccccc1</smiles>

2

1-(Phenylmethyl)-2-methoxy2-oxyethyl-amine hydrochloride<smiles>COC(=O)NC(Cc1ccccc1)C(=O)OC</smiles>

$2-[(\mathrm{N}-$ Methylmethanamine $)$ methyl-carbonyl]a amino-3phenyl-methyl- propanoate

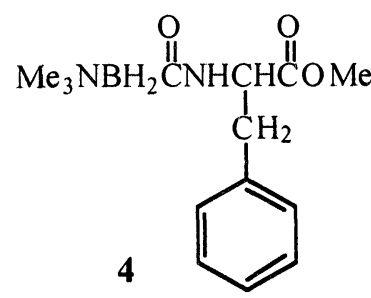

(N,N-dimethylmethanaminedihydro [[[1-(phenylmethyl)-2-methoxy-2oxoethyl]amino] carbonyl ]boron

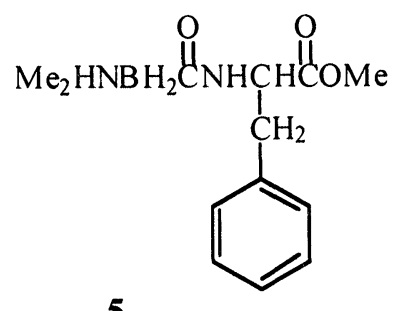

(N-methylmethanamine)di hydro [[]1-(phenylmethyl)-2-methoxy-2oxoethyl]amino]carbonyl]boron

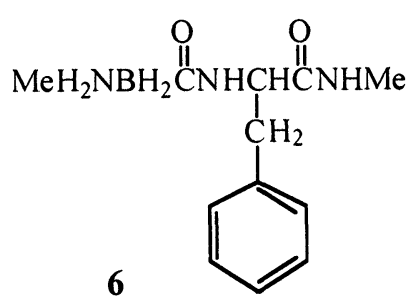

(Methanamine) dihydro[[[1(phenylmethyl)-2-methylamino-2oxoethyl ]amino]carbonyl]boron

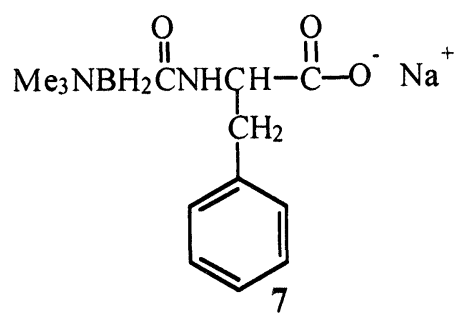

Sodium $-2-\{\mathrm{N}, \mathrm{N}-\mathrm{d}$ imethyl-methanamine dihydroboron -carbonyl]amin 0-3-phenyl -propanoate

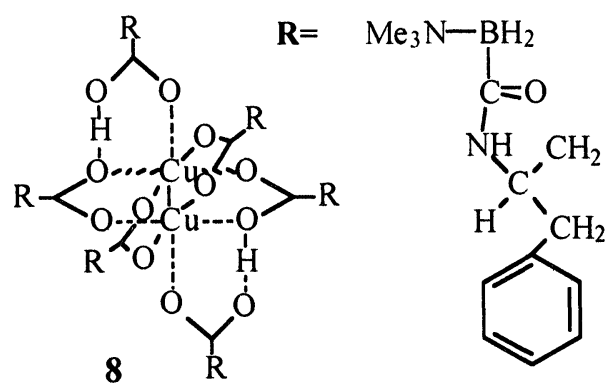

Tetrakis--\{2-[N,N-dimethyl-methanamine $)$ dihydroboron-carbonyl]amino-3-phenyl-propylcarboxylato)-bis-(2-[N, N-di methyl-methanamine ) dihydroboron-carbonyl]amino-3-phenyl-propanoate) dicopper (II)

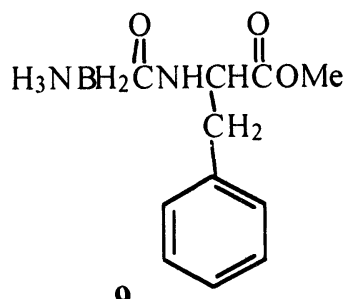

(Ammonia)dihydro[[[1(phenylmethyl)-2-methoxy-2oxoethyl]amino]carbonyl ]boron<smiles>CCCCCCCC(Cc1ccc(O)cc1)C(C)=O</smiles>

(N,N-dimethylm ethanamine) dihydro[[[1-[(4-hydroxyphenyl)methyl]-2-methoxy-2-oxoethyl] amino]carbonyl]boron<smiles>CC(=O)NC(=O)CCc1ccc(O)cc1</smiles>

(N-methylmethanamine) dihydro[[[1-[(4-hydroxyphenyl)methyl]-2-methoxy-2-oxoethyl] amino] carbonyl]boron<smiles>CCCCCCCCC(Cc1ccc(O)cc1)C(=O)NC</smiles>

(Methanamine)dihydro[[[1[(4-hydroxyphenyl)-methyl]2-methylamino-2-oxoethyl] amino]carbonyl]boron 

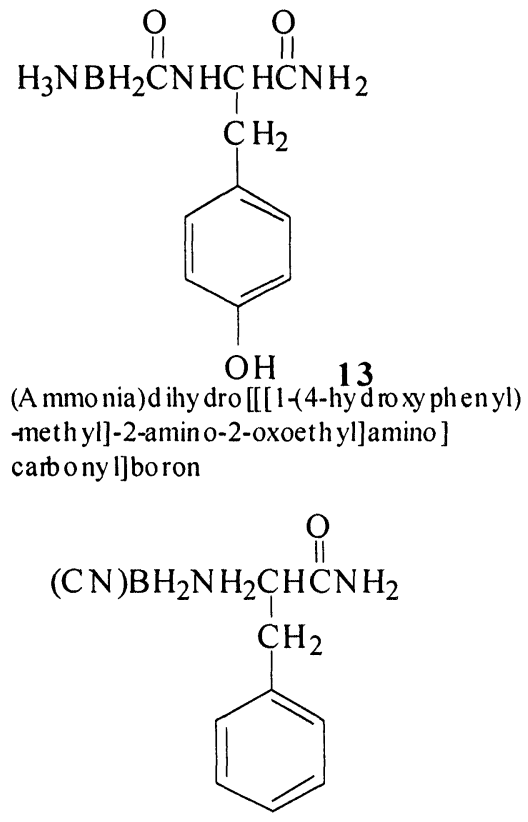

(Cyano) dihy dro [[1-(phenylmethyl)

-2-amin 0-2-oxo ethy 1]amino]boron<smiles>COC(=O)C(Cc1ccccc1)NC(=O)C(Cc1ccc(B(O)O)cc1)NC(C)=O</smiles>

$\mathrm{N}$-acety l-4-bo ro no phen y lalany lp hen ylalan ine methyl ester<smiles>COC(=O)C(Cc1ccc(O)cc1)NC(=O)C(Cc1ccc(B(O)O)cc1)NC(C)=O</smiles><smiles>COC(=O)C(Cc1cnc[nH]1)NC(=O)[Sn](C)(C)C</smiles>

$\mathrm{N}-[($ Trime th y lamine-bo ryl)carbony l]-L-histid ine methy 1 ester<smiles>COC(=O)C(Cc1c[nH]c2ccccc12)NC(=O)[B]S(C)(C)C</smiles>

$\mathrm{N}-[($ T rimeth ylamin e-bo ry l)-carb on $\mathrm{y}] \mathrm{-}$ L-try ptophan methyl ester<smiles>CNBC(=O)N1CCCC1C(=O)OC</smiles>

$\mathrm{N}-[($ trimethy lamin e-bory $\mathrm{l})$-carbo $\mathrm{ny}] \mathrm{-}-$ L-proline methyl ester

$\mathrm{N}$-acetyl-4-bo ro n op heny lalanyltyros ine methyl ester

Figure 1 Structures of Aromatic Boronated Amino Acids 
Anti-inflammatory Activity.

$\mathrm{CF}_{1}$ male mice $(\sim 25 \mathrm{~g})$ were administered drugs at $8 \mathrm{mg} / \mathrm{kg}$ in $1 \% \mathrm{CMC} \mathrm{I.P,} \mathrm{at} 3 \mathrm{~h}$ and again $30 \mathrm{~min}$ prior to the injection in $0.2 \mathrm{ml}$ of carrageenan in $0.9 \%$ saline into the plantar surface of the high hind foot. Saline was injected into the left hind foot which served as the standard base line. After $3 \mathrm{~h}$ both feet were excised at the tibiolarsal (ankle) joint according to the modified method of Winter et al.[21], resulting in $84 \mathrm{mg}$ increase in the paw weight of the control mice.

Local Analgesic Activity-Writhing Reflex.

Male $\mathrm{CF}_{1}$ male mice $(\sim 25 \mathrm{~g})$ were administered test drugs at $8 \mathrm{mg} / \mathrm{kg}$ I.P. 20 min prior to the administration of $0.5 \mathrm{ml}$ of $0.6 \%$ acetic acid, I.P. [22]. After $5 \mathrm{~min}$ the number of stretches, characterized by repeated contractions of the abdominal musculature accompanied by extension of the hind limbs for the next $10 \mathrm{~min}$ were counted. The control mice afforded 61 stretch reflexes in $10 \mathrm{~min}$.

Hot Plate Tail Flick Activity-Central Analgesic Activity.

$\mathrm{CF}_{1}$ male mice $(\sim 28 \mathrm{~g})$ were administered drugs at $8 \mathrm{mg} / \mathrm{kg}$, I.P., $15 \mathrm{~min}$ prior to placement on a hot plate maintained at $100{ }^{\circ} \mathrm{C}$. The time elapse for the tail to be raised from the surface of the hot plate was determined using a digital read-out connected to the hot plate [23]. The tail flick response of the control mice was 12.12 sec.

Endotoxic Shock Protection.

$\mathrm{CF}_{1}$ male mice $(\sim 25 \mathrm{~g})$ were administered Salmonella lipopolysaccharide (LPS) at $10 \mathrm{mg} / \mathrm{kg}$, IP which is a dose that is lethal by $100 \%$ within $48-52 \mathrm{~h} \mathrm{[24]}$. Drugs were administered at $8 \mathrm{mg} / \mathrm{kg}, 2 \mathrm{hr}$ before and $2 \mathrm{hr}$ after the injection of LPS and every $24 \mathrm{~h}$ there after up to $48 \mathrm{~h}$. Deaths were recorded daily for the length of the study. The percentage deaths at $52 \mathrm{~h}$ was calculated and compared to the control value that afforded $16 \%$ survival of the animals at that time.

Table 1 The Hypolipidemic Effects of Boronated Aromatic Amino Acids at $8 \mathrm{mg} / \mathrm{kg} \mathrm{I.P}$ Percent of Control (mean \pm standard deviation)

\begin{tabular}{|c|c|c|c|}
\hline \multirow{2}{*}{\multicolumn{3}{|c|}{ Serum Cholesterol }} & \multirow{2}{*}{$\begin{array}{c}\text { Serum Triglycerides } \\
\text { Day } 16\end{array}$} \\
\hline & & Day 16 & \\
\hline Control $1 \% \mathrm{CMC}$ & $100 \pm 5^{a}$ & $100 \pm 6^{b}$ & $100 \pm 4^{c}$ \\
\hline 1 & $90 \pm 5$ & $90 \pm 6$ & $94 \pm 6$ \\
\hline 2 & $69 \pm 5 *$ & $61 \pm 5 *$ & $63 \pm 5 *$ \\
\hline 3 & $76 \pm 4 *$ & $74 \pm 5 *$ & $80 \pm 5 *$ \\
\hline 4 & $75 \pm 6 *$ & $52 \pm 3 *$ & $67 \pm 5 *$ \\
\hline 5 & $86 \pm 5$ & $69 \pm 5 *$ & $92 \pm 6$ \\
\hline 6 & $75 \pm 4 *$ & $52 \pm 3 *$ & $92 \pm 5$ \\
\hline 7 & $71 \pm 5 *$ & $68 \pm 4 *$ & $88 \pm 5$ \\
\hline 8 & $72 \pm 5 *$ & $63 \pm 4 *$ & $61 \pm 5 *$ \\
\hline 9 & $87 \pm 6$ & $71 \pm 5 *$ & $98 \pm 5$ \\
\hline 10 & $72 \pm 5 *$ & $68 \pm 6 *$ & $55 \pm 5 *$ \\
\hline 11 & $73 \pm 4 *$ & $67 \pm 5 *$ & $68+6 *$ \\
\hline 12 & $73 \pm 5^{*}$ & $74 \pm 4 *$ & $83 \pm 5$ \\
\hline 13 & $82 \pm 6$ & $68 \pm 5 *$ & $96 \pm 6$ \\
\hline 14 & $64 \pm 3 *$ & $55 \pm 4 *$ & $77 \pm 4 *$ \\
\hline 15 & $68 \pm 5 *$ & $62 \pm 4 *$ & $73 \pm 4 *$ \\
\hline 16 & $66 \pm 4 *$ & $65 \pm 6 *$ & $78 \pm 5^{*}$ \\
\hline 17 & $71 \pm 7 *$ & $69 \pm 5 *$ & $65 \pm 6^{*}$ \\
\hline 18 & $75 \pm 3 *$ & $68 \pm 6 *$ & $82 \pm 6$ \\
\hline 19 & $65 \pm 4 *$ & $64 \pm 5 *$ & $82 \pm 5$ \\
\hline Lovastatin $8 \mathrm{mg} / \mathrm{kg}$ & $85 \pm 4$ & $82 \pm 5$ & $86 \pm 7$ \\
\hline $\begin{array}{r}\text { Clofibrate } 150 \mathbf{~ m g} / \mathbf{k g} \\
\quad \mathrm{a}=125 \mathrm{mg} / \mathrm{dL} ; \mathrm{b}=12\end{array}$ & $\begin{aligned} & 88 \pm 4 \\
= & 137 \mathrm{~m}\end{aligned}$ & $78 \pm 5$ & $75 \pm 5 *$ \\
\hline
\end{tabular}

Enzyme Assays.

$\mathrm{CF}_{1}$ livers were homogenized in $0.25 \mathrm{M}$ sucrose $+0.001 \mathrm{M}$ EDTA, $\mathrm{pH}$ 7.2. Mouse macrophages J774A were maintained in Dulbecco's modified medium (DMEM) $+15 \%$ fetal calf serum $+\mathrm{P} / \mathrm{S}$ were homogenized. 
All of the methods for the enzyme studies have been described previously [16]. Acid phosphatase, elastase, trypsin and cathepsin activities were determined after $30 \mathrm{~min}$ incubation of drugs at $10^{-8} \mathrm{M}$ prepared in $1 \%$ $\mathrm{CMC}$ at $37^{\circ} \mathrm{C}$. Acid phosphatase activity was determined using $0.1 \mathrm{M} \beta$-glycerolphosphate in $0.1 \mathrm{M}$ acetate buffer, $\mathrm{pH}$ 5.0. The reaction was stopped with $10 \% \mathrm{TCA}$ and centrifuged at $3000 \times \mathrm{g} \times 6 \mathrm{~min}$. The supernatant inorganic phosphate was determined by the spectrophotometric method. The net inorganic phosphate released from $30 \mathrm{~min}$ was corrected by subtracting the blank. Cathepsin activity was determined using $2 \%$ azocasein as the substrate in $0.1 \mathrm{M}$ acetate buffer, $\mathrm{pH} 5.0$ and the hydrolyzed acid-soluble peptide fragment was analyzed at $366 \mathrm{~nm}$ and corrected for the blank. Trypsin proteolytic activity was determined by the method of Schleuning and Fritz [25] using $6 \mathrm{mM}$ N-benzoly-L-arginine ethyl ester (BAEE) in $0.1 \mathrm{M}$ Tris buffer, $\mathrm{pH}$ 8.0. The hydrolyzed product was determined at $253 \mathrm{~nm}$ and the blank subtracted. Elastase activity was determined by the method of Kleinerman et al. [26] with 2 units of porcine pancreatic elastase (Sigma, Type III), $\mathrm{N}$-succinyl-L-alanyl-L-alanine-p-nitroanilide (Sigma, $100 \mathrm{mg}$ in $5 \mathrm{ml}$ methyl-2-pyrrolidone) in 0.2 $\mathrm{M}$ Tris buffer, $\mathrm{pH} 8.0$. The cleaved product $p$-nitroanilide was determined at $410 \mathrm{~nm}$ and the blank substracted.

Table 2 The Anti-inflammatory Effects of Boronated Aromatic Amino Acids at $8 \mathrm{mg} / \mathrm{kg} \mathrm{I.P}$ Percent of Control (mean \pm standard deviation) $\quad \mathrm{N}=6$

\begin{tabular}{|c|c|c|c|c|}
\hline & $\begin{array}{l}\text { Anti } \\
\text {-inflammatory }\end{array}$ & Writhing & $\begin{array}{c}\text { Hot Plate } \\
\text {-Tail Flick }\end{array}$ & $\begin{array}{l}\text { LPS } \approx \\
\text {-Protection }\end{array}$ \\
\hline Control & $100 \pm 5$ & $100+\underline{4}$ & 100 & 16 \\
\hline 1 & $83 \pm 5$ & $77 \pm 5^{*}$ & 107 & 17 \\
\hline 2 & $90 \pm 4$ & $50 \pm 4 *$ & & 83 \\
\hline 3 & $68 \pm 7^{*}$ & $48 \pm 3 *$ & 113 & 100 \\
\hline 4 & $68 \pm 5^{*}$ & $48 \pm 5$ & 139 & 33 \\
\hline 5 & $60 \pm 5^{*}$ & $15+3 *$ & 85 & 100 \\
\hline 6 & $77 \pm 5^{*}$ & $83 \pm 4$ & & 100 \\
\hline 7 & $60 \pm 6^{*}$ & $97 \pm 5$ & 83 & 83 \\
\hline 8 & $107 \pm 6$ & $97 \pm 6$ & 120 & 67 \\
\hline 9 & $80 \pm 5$ & $16+2 *$ & & 83 \\
\hline 10 & $63 \pm 4 *$ & $25+4 *$ & 148 & 83 \\
\hline 11 & $70 \pm 5^{*}$ & $19 \pm 3^{*}$ & 218 & 100 \\
\hline 12 & $72 \pm 4 *$ & $21 \pm 4 *$ & 131 & 100 \\
\hline 13 & $68 \pm 3^{*}$ & $15 \pm 3 *$ & 189 & 83 \\
\hline 14 & $59 \pm 4 *$ & $42 \pm 4 *$ & 96 & 83 \\
\hline 15 & $76 \pm 4 *$ & & & \\
\hline 16 & $75 \pm 4 *$ & & & \\
\hline 17 & $70 \pm 7 *$ & $104 \pm 6$ & & 67 \\
\hline 18 & $94+7$ & $94 \pm 4$ & & 83 \\
\hline 19 & $70+4+8$ & $83 \pm 4$ & & \\
\hline \multicolumn{5}{|l|}{ Standards } \\
\hline Indomethacin $8 \mathrm{mg} / \mathrm{kg}$ & $74+4 *$ & $43 \pm 4 *$ & & 50 \\
\hline Phenyl-butazone $50 \mathrm{mg} / \mathrm{kg}$ & $53 \pm 4 *$ & & & \\
\hline Morphine $1 \mathrm{mg} / \mathrm{kg}$ & -- & & 213 & \\
\hline Dexamethasone $1 \mathrm{mg} / \mathrm{kg}$ & -- & & & 67 \\
\hline Pentoxifylline $50 \mathrm{mg} / \mathrm{kg}$ & -- & & & 67 \\
\hline
\end{tabular}

The control values for these assays are located in the Methods section.

\section{RESULTS}

The boronated amino acids and their metal complexes demonstrated significant hypolipidemic effects in mice at $8 \mathrm{mg} / \mathrm{kg}$ I.P. [Table 1]. Compounds 6 and 14 caused greater than $40 \%$ reduction of total serum cholesterol levels after 16 days. Compounds 2, 4, 5, 7, 8, 10, 11, 13 and 15-19 afforded greater than $30 \%$ reduction of serum cholesterol after 16 days which was significantly better than the standards clofibrate and lovastatin at their therapeutic doses. Serum triglycerides were reduced $45 \%$ by compound 10 . Compounds $2, \mathbf{6}, \mathbf{8 , 1 1}$ and 
17 lowered serum triglyceride levels greater than 30\% which was greater than the standards' effects. LPhenylalanine itself was not active in either assay. The addition of the methyl ester did result in an active compound indicating that the boron atom was not necessarily important for hypolipidemic activity in mice.

The boronated aromatic amino acid demonstrated anti-inflammatory activity in mice [Table 2] with compounds $3-5,7,10,13,14$ and phenylbutazone demonstrating greater than $30 \%$ inhibition of edema. Compounds $6,11,12,15,16,17,19$ and indomethacin caused greater than $20 \%$ reduction. Compounds 2-5, 9-14 and indomethacin afforded at least 50\% inhibition of the local analgesic writhing reflex. Central analgesic activity similar to that demonstrated by morphine at $1 \mathrm{mg} / \mathrm{kg}$ with an increase of $113 \%$ above the control value was observed for compounds 11 and 13 which demonstrated increases of $118 \%$ and $89 \%$, respectively at $8 \mathrm{mg} / \mathrm{kg}$. Compounds 4, 8, 10 and 12 demonstrated a significant increase but were not as potent as morphine. Protection of $100 \%$ against LPS induced endotoxin induced shock was afforded by compounds 3, 5, 6, 11 and 12 at $8 \mathrm{mg} / \mathrm{kg}$. Compounds $2,7,9,10,13,14$ and 18 caused $83 \%$ protection which was better than compound 8 and 17 at $8 \mathrm{mg} / \mathrm{kg}$ and dexamethasone at $1 \mathrm{mg} / \mathrm{kg}$ and pentoxifylline at $50 \mathrm{mg} / \mathrm{kg}$ which caused $67 \%$ protection in mice.

The boronated aromatic amino acids in vitro demonstrated the ability to suppress the activities of proteolyic and lysosomal hydrolytic enzymes in $\mathrm{CF}_{1}$ mouse liver homogenates and cultured mouse $\mathrm{J} 774 \mathrm{~A}$ macrophages [Table 3]. In mouse liver compounds 3-5, 7, 12-17 and 19 afforded greater than $40 \%$ inhibition of elastase activity. Liver cathepsin activity was reduced greater than $30 \%$ by compounds $4,5,7,913,17$ and 19 . Liver trypsin proteolytic activity was suppressed $94 \%$ by compound 7, but compounds 11-17 caused greater than $50 \%$ reduction of activity. In the cultured mouse macrophages elastase activity was reduced at least $30 \%$ by compounds 3, 5, 8 10, 12, 15 and 17. Macrophage cathepsin activity was inhibited greater than $35 \%$ by compounds $5,11,12,14,16,17$, and 19 . Trypsin activity was reduced at least $30 \%$ by compounds 10 and 16. Macrophage acid phosphatase activity was reduced $40 \%$ by compound 5 and $30 \%$ by compound 13 .

Table 3 The Effects of Boronated Aromatic Amino Acid on Lysosomal Enzyme Activities Percent of Control (Standard Deviations)

\begin{tabular}{|c|c|c|c|c|c|c|c|}
\hline \multirow{3}{*}{$\underset{\text { Control }}{\mathrm{N}=4}$} & \multicolumn{3}{|c|}{ 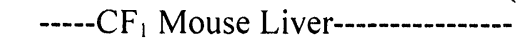 } & \multicolumn{4}{|c|}{ 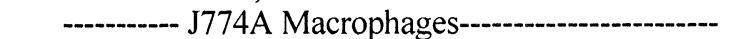 } \\
\hline & Elastase & Cathepsin & Trypsin & Elastase & Cathepsin & Trypsin & Acid phosphatase \\
\hline & $100 \pm 5$ & $100 \pm 4$ & $100 \pm 7$ & $100 \pm 5$ & $100 \pm 6$ & $100 \pm 4$ & $100 \pm 5$ \\
\hline 1 & $99 \pm 4$ & $96 \pm 5$ & $97 \pm 4$ & $103 \pm 5$ & $98 \pm 5$ & $102 \pm 6$ & $97 \pm 7$ \\
\hline 2 & $78 \pm 5^{*}$ & $86 \pm 6$ & $87 \pm 5$ & $73 \pm 4 *$ & $84 \pm 5$ & $92 \pm 5$ & $81 \pm 4 *$ \\
\hline 3 & $53 \pm 3 *$ & $75 \pm 4 *$ & $135 \pm 7 *$ & $67 \pm 4 *$ & $89 \pm 6$ & $74 \pm 5^{*}$ & $76 \pm 4 *$ \\
\hline 4 & $43 \pm 4 *$ & $65 \pm 5^{*}$ & $79 \pm 4 *$ & $73 \pm 4 *$ & $113 \pm 5$ & $76 \pm 5^{*}$ & $93 \pm 6$ \\
\hline 5 & $48+\underline{3}^{*}$ & $66 \pm 3 *$ & $142 \pm 5 *$ & $68+3 *$ & $54 \pm 3 *$ & $82 \pm 5$ & $60 \pm 4^{*}$ \\
\hline 6 & $74 \pm 4 *$ & $75 \pm 3 *$ & $95 \pm 5$ & $82 \pm 6$ & $74 \pm 4 *$ & $80 \pm 3 *$ & $88 \pm 6$ \\
\hline 7 & $51 \pm 4^{*}$ & $60 \pm 4 *$ & $6 \pm 2 *$ & $72 \pm 5^{*}$ & $93 \pm 5$ & $94 \pm 6$ & $97 \pm 5$ \\
\hline 8 & $68 \pm 4^{*}$ & $73 \pm 5^{*}$ & $81 \pm 4 *$ & $69 \pm 4^{*}$ & $71 \pm 5^{*}$ & $81 \pm 5^{*}$ & $91 \pm 4$ \\
\hline 9 & $73 \pm 4^{*}$ & $67 \pm 3 *$ & $74 \pm 4^{*}$ & $78 \pm 5^{*}$ & $79 \pm 4 *$ & $86 \pm 4$ & $99 \pm 6$ \\
\hline 10 & $65 \pm 5^{*}$ & $72 \pm 4 *$ & $117 \pm 6$ & $67 \pm 6^{*}$ & $89 \pm 6$ & $68 \pm 5^{*}$ & $95 \pm 5$ \\
\hline 11 & $60 \pm 4^{*}$ & $85 \pm 5$ & $30 \pm 3^{*}$ & $82 \pm 5$ & $57 \pm 5^{*}$ & $88 \pm 5$ & $85 \pm 5$ \\
\hline 12 & $59 \pm 4 *$ & $91 \pm 6$ & $41 \pm 4 *$ & $63 \pm 4 *$ & $61 \pm 5^{*}$ & $90 \pm 6$ & $104 \pm 7$ \\
\hline 13 & $49 \pm 3^{*}$ & $66 \pm 5^{*}$ & $31 \pm 3 *$ & $70 \pm 5^{*}$ & $72 \pm 4 *$ & $104 \pm 5$ & $70 \pm 4^{*}$ \\
\hline 14 & $54 \pm 4 *$ & $88 \pm 4$ & $38 \pm 3 *$ & $76 \pm 5 *$ & $51 \pm 4 *$ & $76 \pm 5 *$ & $91 \pm 6$ \\
\hline 15 & $55 \pm 6 *$ & $75 \pm 5^{*}$ & $36 \pm 2 *$ & $69 \pm 6^{*}$ & $94 \pm 6$ & $84 \pm 6$ & $103 \pm 5$ \\
\hline 16 & $57 \pm 4^{*}$ & $74 \pm 3 *$ & $44 \pm 4 *$ & $82 \pm 7$ & $57 \pm 4^{*}$ & $57 \pm 4 *$ & $94 \pm \overline{4}$ \\
\hline 17 & $54 \pm 3 *$ & $68 \pm 3 *$ & $44 \pm 5^{*}$ & $65 \pm 6 *$ & $62 \pm 5^{*}$ & $81 \pm 4 *$ & $108 \pm 5$ \\
\hline 18 & $63 \pm 7 *$ & $71 \pm 4 *$ & $62 \pm 4^{*}$ & $76 \pm 5^{*}$ & $66 \pm 4^{*}$ & $71 \pm 3^{*}$ & $90 \pm 5$ \\
\hline 19 & $58 \pm 5^{*}$ & $68 \pm 4^{*}$ & $81 \pm 5$ & $96 \pm 6$ & $57 \pm 4 *$ & $96 \pm 5$ & $85+4$ \\
\hline
\end{tabular}

\section{DISCUSSION}

The boronated aromatic peptides demonstrated good hypolipidemic activity that was consistent with other boronated compounds. They perhaps were more effective in lowering serum cholesterol levels after 16 days than lowering serum triglycerides levels. (N,N-dimethylmethanamine)dihydro[[[1-(phenylmethyl)-2-methoxy- 
2-oxoethyl]amino]carbonyl]boron 4 and (cyano)dihydro[[1-(phenylmethyl)-2-amino-2-oxoethyl]amino]boron 14 appear to be the best compounds in this respect and they were markedly more

potent at $8 \mathrm{mg} / \mathrm{kg}$ than the standards clofibrate at $150 \mathrm{mg} / \mathrm{kg}$ and lovastatin at $8 \mathrm{mg} / \mathrm{kg}$. There did not appear to significant differences between the phenylalanine, tyrosine, proline, histidine and tryptophan derivatives and their effects on lowering cholesterol levels. (N,N-dimethymethanamine)dihydro[[[1-(4hydroxyphenyl)methyl)-2-methoxy-2-oxoethyl]amino]carbonyl]boron $\mathbf{1 0}$ was the most potent agent in lowering serum triglyceride levels on day 16. Again this magnitude of reduction of triglycerides was highly significant compared to the standard drug effects on this lipid component.

Their anti-inflammatory effects of the boronated aromatic amino acids was not as significant as those observed for the $\alpha$-amino boranes [16]. The sodium-2-(N,N-dimethylmethanamine)dihydroboron carbonyl)amino-3phenylpropanoate 7 (cyano)dihydro[[1-(phenylmethyl)-2-amino-2-oxoethyl]aminoboron 14 achieved the same degree of reduction of induced edema as the standard phenylbutazone at $50 \mathrm{mg} / \mathrm{kg} \times 2$. The agents were better in reducing local pain [writhing] with (methanamine)dihydro[[[1-(phenylmethyl)-2-methylamino-2oxoethyl]amino]carbonyl]boron 5 as well as the tyrosine derivatives 9-13 affording better activity than the standard indomethacin. The other boronated aromatic amino acids were not significantly active in reducing local pain. (N-methylmethanamide)dihydro[[[1-(4-hydroxyphenylmethyl)-2-methoxy-2-oxoethyl ]amino]carbonyl]boron 11 was the only compound that was as active as morphine in reducing central pain although compound 13 was significantly effective. The phenylalanine derivatives did not demonstrate any ability to block central pain. The boronated aromatic acids did protect the mouse from LPS induced shock and many of the tested derivatives were more potent than the standards dexamethasone and pentoxifylline at their therapeutic doses. Those compounds without a boron atom, compounds $\mathbf{1}$ and $\mathbf{2}$ offered no protection against LPS induced shock. Previously amine-carboxyboranes were shown to inhibit proteolytic and lysosomal hydrolytic enzyme activities [16]. The present study would suggest that similar mechanisms of action are caused by the boronated aromatic amino acids for their anti-inflammatory activity. The aminecarboxyboranes also suppressed prostaglandin synthetase and cytokine, e.g. Il-1 and TNF $\alpha$ release as well as the migration of white cells to the inflammation site [16]. Whereas further investigation of this group of compounds is required, they may offer some therapeutic use in the future because of the low dose required for their in vivo activity as hypolipidemic and anti-inflammatory agents.

Refereences

1. C.K. Sood, A. Sood, B.F. Spielvogel and I.H. Hall, Eur. J. Med. Chem. 1990, 25, 301-308.

2. I.H. Hall, E.S. Hall, M.C. Miller, III, A. Sood and B.F. Spielvogel, Amino Acids 1993, 4 , 287-302.

3. S. Karthikeyan, A.Sood, J. Tomasz, B.F. Spielvogel and I.H. Hall, Amino Acids 1995, 8, 323-335.

4. M.C. Miller, A. Sood, B.F. Spielvogel and I.H. Hall, Anticancer Res. 1997, 17, 3299-3306.

5. M.C. Miller, A. Sood, B.F. Spielvogel and I.H. Hall, Met.Based Drugs, 5, 1-9, 1997.

6. M.C. Miller, III< A. Sood, B.F. Spielvogel, R.P. Shrewsbury and I.H.Hall, Met.Based Drugs 1996, 3, 219-226.

7. I.H. Hall, B. F. Spielvogel, A.T. McPhail and W.L. Williams, Jr. J. Pharm Sci 1984, 73, 973-977.

8. I.H. Hall, B. F. Spielvogel, T. S. Docks and B.J. Brotheron, Res. Commun. Chem. Pathol, Pharmocol. $1989,65,297-317$.

9. I.H. Hall, A. Sood and B.F. Spielvogel, Biomed. Pharmther. 1991, 45, 333-341.

10. I.H. Hall, B.S. Burnham, B.R. Shaw, K.G. Rajendran, A. Sood and B.F. Spielvogel, Biomed. Pharmther. 1993, 47, 79-87.

11. I.H.Hall, S. Y. Chen,, K.G. Rajendran , A. Sood and B.F. Spielvogel, Envir. Health Persp. 1994, 102, Suppl. 3, 211-214.

12. I.H. Hall, D.J. Reynolds, O.T. Wong, A. Sood and B.F. Spielvogel, Met. Based Drugs 1995, 2, 65-72.

13. B.S. Burnham, A. Sood, B.F. Spielvogel, S.Y. Chen and I.H. Hall, Met. Based Drugs 1996, 3, 173183.

14. I.H. Hall, K. G. Rajendran, S.Y. Chen, V.M. Norwood III, K.W. Morse, A. Sood, and B.F. Spielvogel, Appl. Oranomet. Chem. 1994, 8, 473-480.

15. K.G. Rajendran, B.S. Burnham, S.Y. Chen, A. Sood, B.F. Spielvogel, B.R. Shaw and I.H. Hall, J. Pharm. Sci. 1994, 83, 1391-1395.

16. I. H. Hall, K.G. Rahendran, S.Y. Chen, O.T. Wong, A. Sood, and B.F. Spielvogel, Arch. Pharm. 1995, 328, 39-44.

17. K.G. Rajendran, A. Sood, B.F. Spielvogel, I.H. Hall, V.M. Norwood, III and K.W. Morse, Appl. Organomet. Chem. 1995, 9, 111-119. 
18. I.H. Hall, B.S. Burnham, S.Y. Chen, A. Sood, B.F. Spielvogel and K. W. Morse, Met. Based Drugs 1995, 2, 1-12.

19. K.G. Rajendran, S.Y. Chen, A. Sood, B.F. Spielvogel and I.H. Hall, Biomed. Pharmther. 1995, 49, 131-140.

20. A.T. Ness, J.V. Pastewka and A.C.Peacock, Clin. Chem. Acta 1964, 10, 229-237.

21. C.A. Winter, E. Risley and G. Nuss, Proc. Soc. Expt. Biol. Med. 1992, 111, 544-547.

22. A.P. Roszkowski, W.H. Rooks, A. Tomonlonis and L.M. Miller, J. Pharm. Exp. Ther. 1971, 179, 114-123.

23. I.H. Hall, J.E. Hall, M. Mohseni, Z. Sajadi, J. Pharm. Sci. 1980, 69, 1451- 1452.

24. L. Noronha-Blob, V.C. Lowe, M. Weitzberg, R.M. Burch, Eur. J. Pharm. 1991, 387-388.

25. W.D. Scleuning, H.Fitz, Meth. Enzymolog. 1976, 1117-1139.

26.J. Kleinerman, V. Ranga, J. Rynbrant, J. Sorensen, J. Powers, Am.Rev.Respir. Dis. 1980, 121,381-387.

Received: June 29, 1999 - Accepted: August 24, 1999 -

Received in revised camera-ready format: August 25, 1999 